\title{
THREE-DIMENSIONAL MAPS OF VEGETATION SERIES AND GEOSERIES WITH THE USE OF STEREOGRAMS
}

\author{
Franco PEDROTTI \\ University of Camerino, Palazzo Castelli, Via Pontoni 5, I-62032 Camerino (MC), Italy \\ e-mail: franco.pedrotti@unicam.it
}

\begin{abstract}
This work presents a three-dimensional model for vegetation mapping at different levels of integration by using a stereogram. The classic method used in vegetation cartography is that of vegetation maps (bidimensional model). Tri-dimensional mapping through stereograms represents a step forward because it emphasizes the relationships between vegetation distribution and physical factors (orography and geomorphology), and climatic ones (phytoclimate). The area mapped is the Altipiano di Piné (the Piné Highland), located between 800 and $1600 \mathrm{~m}$ of altitude in the central Alps, Trentino, Italy. Three stereograms were produced, one for the vegetation series (16), one for the geoseries (9) and one for the phytoclimatic sectors (2). The use of stereograms is particulary useful for mapping areas of limited extension displaying a high beta-diversity of vegetation, which is determined by a wide altitudinal range, and/or heterogeneous geomorphotypes and mesoclimatic types (medium-scale environmental heterogeneity).
\end{abstract}

Key words: altitudinal range, beta-diversity, central Alps, environmental heterogeneity, Italy, landscape phytosociology, geomorphotypes, phytoclimate

\section{Introduction}

With the development of studies in the sector of landscape phytosociology (vegetation series and geoseries), three-dimensional models for representing plant associations as well as vegetation series and geoseries have been proposed (Rivas Martìnez, 1987; Rivas Martìnez et al., 2007, 2011a, 2011b). These models are very interesting because of two aspects: a) they provide a virtual visualization of the vegetation series, since each series is composed of various plant associations, from pioneer to climax ones; and b) they provide a spatial image of the various plant associations in a given location, also in relation to the orography and geomorphology.

The classical method used in vegetation cartography is that of vegetation maps (bidimensional models), which can be realized with the use of topographical maps (Rivas Martinez, 1987; Pedrotti, 2004, Bioret, 2012), and aerial photographs (Bioret et al., 2014; Perrin, 2014).

The goal of this paper was to present a tri-dimensional model of cartography of vegetation series and geoseries by employing a stereogram.

\section{Materials and Methods}

Vegetation series and geoseries were surveyed using classic methods (altimeter, compass, aerial photographs, field work along established itineraries). The series and geoseries were delineated on the basis of previously prepared vegetation maps (Pedrotti and Chemini, 1981; Pedrotti, 1981; Pedrotti and Gafta, 1997; Pedrotti, 2004), with further assessments on site, while the phytoclimatic sectors were delineated on the basis of the phytoclimate map of the TrentinoAlto Adige Region (Gafta and Pedrotti, 1998).

In order to obtain a tri-dimensional model of representation, the distribution of mapping 
units was placed on a specially prepared stereogram performed by Prof. Livio Trevisan for a study of the geomorphology of the area (Trevisan, 1943).

\section{Environmental features}

The Altopiano di Piné (Trentino, central Alps) corresponds to a high valley suspended over a more deeply cut nearby valley, caused by glacial over-excavation and fluvial erosion, the Cembra Valley. It is located on the last southern ramification of the Lagorai group of mountains, between 800 and $2452 \mathrm{~m}$ a.s.1.. The sector studied corresponds to the stereogram in Fig. 1, and lies between 800 and $1600 \mathrm{~m}$ of altitude.

The lithological substratum is formed of quartziferous porphyry of the Permian Period of different ages and types, whose flows reached the Valsugana in the section between Pergine and the Le Sille area. The upper part of the flows is flat, at an elevation between 800 and $1100 \mathrm{~m}$, and corresponds to a highland. This part is bordered by mountain reliefs, which on the right include the Monte Calvo crestline $(1411 \mathrm{~m})$, La Brada $(1583 \mathrm{~m})$, and Dosso di Costalta (slopes up to $1600 \mathrm{~m}$ ), while the right is formed of the Dossi di Tressilla (800-900 m), Dossi di Baselga (800$1000 \mathrm{~m})$ and Ceramonte $(1514 \mathrm{~m})$.

The geomorphology is of glacial origin (Trevisan, 1943) and further shaped by glacier abrasion. In various locations one observes surfaces of porphyry smoothed and striated by glaciers. On a cliff slightly above Baselga di Piné there is a rare example of pothole formed in the porphyry (Mazzoleni, 1929). Thus a vast deposition of morenic material happened in the flat part and on the lower part of the slopes.

The soils of the wet and swampy areas are hydromorphous, whereas those of the palustrine areas with emergent phreatic waters are of organic type. Those of the slope detritus, morenic deposits and porphyritic rocks are brown-acidic soils (Lanzinger and Sartori, 2004). On the slopes of the Dosso di Costalta there are also podzolic soils.

The action of glaciers caused the formation of various glacial basins, lakes and peatbogs (e.g., Serraia, Laghestel, Miola, the latter indicated with "torbiera" on the stereograms). In Laghestel the deposit of peat reaches a thickness of $8 \mathrm{~m}$ (Lona, 1941).

Fluvial erosion led to the formation of two fairly narrow valleys that cut through the highland, namely the Sila torrent, a runoff from Serraia Lake, and the Rio Negro, which arises in correspondence with the "peatbog" of Miola.

The Piné Highland is at the border between the prealpic and alpic sectors (Gafta and Pedrotti, 1998). Passing from the prealpic sector $(600 \mathrm{~m})$ to the alpic one $(1600 \mathrm{~m}$, which is the highest altitude of the stereogram), the climatic gradient is determined by the following succession: upper mesotemperate humid prealpic, lower supratemperate humid prealpic, lower supratemperate humid alpic and upper supratemperate subhumid alpic. At higher altitudes, outside the study area, there is also the orotemperate humid alpic climate. In the prealpic sector there is a widespread presence of hardwoods (Quercus petraea, Fagus sylvatica and Fraxinus excelsior, which, however, also occur into the alpic sector, while in the in the alpic sector, there is a widespread presence of conifers (Picea abies, Larix decidua and Pinus cembra).

\section{Plant associations}

The flat part of the highland $(800-1200 \mathrm{~m})$ is occupied by forests of Luzulo niveaeQuercetum petraeae and Vaccinio vitis-idaeae-Pinetum sylvestris. The slopes (1200-1600 m) 
host Luzulo niveae-Fagetum in the prealpic sector and Larici-Pinetum cembrae in the alpic one. They are all zonal associations, except for Vaccinio vitis-idaeae-Pinetum sylvestris, which is considered extrazonal (Pedrotti, 2004).

The azonal vegetation is represented by the alderwood (Stellario nemorum-Alnetum glutinosae) along watercourses and on conoids, and by alderwoods and swampy willowwoods (Carici elongatae-Alnetum glutinosae, Carici elatae-Alnetum glutinosae and Salicetum pentandrae) in the glacial basins.

The valley bottoms and the lower parts of the slopes have been deforested and are now occupied by mown grasslands (Centaureo-Arrhenatheretum and, in part, MelandrioArrhenatheretum) and by cultivated areas.

Under the new socio-economic conditions, there has been an abandonment of many meadows, both mesophilous and hygrophilous, and they are no longer mown. In abandoned meadows of Centaureo-Arrhenatheretum, the secondary succession leads to the formation of Corylo-Populetum tremulae; the colonization of the wet meadows (Junco-Molinietum, Lysimachio-Filipenduletum and Scirpetum sylvatici) occurs through the great development of Alnus glutinosa stands (Gafta and Canullo, 1992; Pedrotti, 1988 and 2006). Farming has been also abandoned throughout the area, except for the fertile plains of the Pian delle Meie. Some former field crops, often supported by stone walls without mortar, have been transformed into hay meadows.

Anthropization and water pollution have led to the disappearance of some typical plant associations of oligotrophic waters, namely Caricetum lasiocarpae and Rhynchosporetum albae, which no longer exist in Piné. On the other hand, subsequent to the arrival of numerous neophytes (Pedrotti, 2010), new plant associations have formed, for example EuphorbioGalinsogetum ciliatae and Convolvulo arvensis-Brometum inermis. These changes are also reflected in the vegetation series that, on one hand, have a dearth of autochthonous associations, and, on the other hand, are enriched by plant associations of neoformations, formed of species with wide distribution (cosmopolitans).

The hay meadows (Centaureo-Arrhenatheretum and Melandrio-Arrhenatheretum) were not associated with any vegetation series, because these grasslands were formed in areas profoundly modified by man, through the construction of walls to support the slopes and other actions, as clearly shown for the vegetation series of the Val di Sole (Pedrotti, in print - b).

Other synanthropic associations of the inhabited areas and country roads do not belong to any vegetation series: they are recalled here to provide the most complete information possible: Asplenietum rutae-murariae-trichomanis, Conyzo canadensis-Lactucetum serriolae, Eragrostio minoris-Polygonetum arenastri, Melilotetum albi-officinalis, Polygonetum arenastri, Lolietum perennis, Polygonetum arenastri, Poo compressae-Tussilaginetum farfarae, Sedo albi-Poëtum compressae, Setario viridis-Erigeronetum canadensis, Poëtum annuae, Sagino-Bryetum argentei, Hordeetum murini, Erigeronto-Lactucetum serriolae (Pedrotti, 2013). The nitrophilous vegetation is represented by Portulacetum oleraceae, Heracleo sphondylii-Rumicetum obtusifolii, Urtico urentis-Chenopodietum boni-henrici and Rumicetum alpini, the latter two associations in habitats close to the study area, but outside it.

Also present are the following plant associations dominated by invasive species: Salici capreae-Buddlejetum davidii, on the detritus of porphyry quarries; shrubwood patches of Robinia pseudacacia, Robinietum s.l.; communities of Solidago canadensis and Solidago 
gigantea in uncultivated areas and abandoned fields.

On the banks of the Serraia Lake the following plant associations occur: Juncetum macri, Juncetum bufonii, Lolio-Potentilletum anserinae, Bidentetum tripartitae, Junco compressiTrifolietum repentis, Malachietum aquatici, Impatientetum parviflorae, Epilobio hirsutiFilipenduletum, Chaerophyllo hirsuti- Filipenduletum, Lemnetum minori. On the shores of Laghestel Lake the following associations are distributed: Caricetum goodenowii, Equiseto fluviatilis-Caricetum rostratae, Phragmitetum vulgaris, Typhetum latifoliae, also present in Pian delle Meie, community of Sparganium erectum, Juncetum macri, Juncetum bufonii, Lemnetum minoris, Fontinaletum antipyreticae and Glycerietum plicatae (little streams), Trichophoretum alpini (in a small peatbog).

\section{Vegetation series}

The vegetation series of Piné highland are zonal (6), intrazonal (1), extrazonal (1) and azonal (8). The series of lake vegetation on organic substrates has been counted as one, but includes several plant associations (8), as can be seen from the number of associations listed.

For each vegetation series, the following news is reported: a) definition of the series according to Pedrotti $(2017 \mathrm{~b})$; b) a list of the plant associations constituting the series; c) chorology of the series in the area corresponding to the stereogram.

1. Orotemperate, alpic, humid, acidophilous (porphyritic) series of Pinus cembra [Larici-Pineto cembrae sigmetum]; zonal, metamorphic-magmatic; developed on podzolic soils; northern slopes of Dosso di Costalta.

Forest (Larici-Pinetum cembrae)

Vegetation of clearings (Senecioni sylvatici-Epilobietum angustifolii, Rubetum idaei)

Meadow (Sieversio montanae-Nardetum)

2. Upper supratemperate, alpic, humid, acidophilous (porphyritic), series of Picea abies and Larix decidua [Larici-Piceeto sigmetum]; zonal, metamorphic-magmatic; developed on podzolic soils; northern slopes of Dosso di Costalta.

Forest (Larici-Piceetum)

Vegetation of clearings (Senecioni sylvatici-Epilobietum angustifolii, Rubetum idaei, Salicetum capreae)

Meadow (Sieversio montanae-Nardetum)

3. Lower supratemperate, alpic, humid, acidophilous (porphyritic) series of Picea abies and Luzula nemorosa [Luzulo nemorosae-Piceeto abietis sigmetum]; zonal, magmatic effusive; developed on podzolic soils; northern slopes of Dosso di Costalta.

Forest (Luzulo nemorosae-Piceetum abietis)

Scrub (Corylo-Populetum tremulae)

Vegetation of clearings (Senecioni sylvatici-Epilobietum angustifolii, Rubetum idaei, Salicetum capreae)

Meadow (Sieversio montanae-Nardetum)

4. Lower supratemperate, European, humid, acidophilous (porphyritic) series of Pinus sylvestris 
and Calluna vulgaris [Vaccinio vitis-idaeae-Pineto sylvestris sigmetum]; extrazonal, prealpic and alpic, metamorphic-magmatic; developed on acid brown soils; common.

Forest (Vaccinio vitis-idaeae-Pinetum sylvestris)

Heath (Chamaecytiso hirsuti-Callunetum)

Rock pioneer vegetation (Sileno rupestris-Asplenietum septentrionalis)

5. Lower supratemperate, prealpic, humid, acidophilous (porphyritic) series of Fagus sylvatica [Luzulo niveae-Fageto sigmetum]; zonal metamorphic-magmatic; developed on acid brown soils; western slopes of Monte Calvo and Monte La Brada.

Forest (Luzulo niveae-Fagetum)

Scrub (Corylo-Populetum tremulae)

Vegetation of clearings (Senecioni sylvatici-Epilobietum angustifolii, Rubetum idaei, Galeopsietum speciosae)

Weed vegetation in crops (Galinsogo-Portulacetum, Euphorbio-Galinsogetum ciliatae)

6. Upper mesotemperate, prealpic and alpic, humid, acidophilous series of Fraxinus excelsior [Salvio glutinosae-Fraxineto excelsioris sigmetum]; zonal, metamorphic-magmatic, porfiric, moraines; common.

Forest (Salvio glutinosae-Fraxinetum excelsioris)

Scrub (Corylo-Populetum tremulae)

Synanthropic vegetation (Impatientetum parviflorae, Sambucetum nigrae, Tanaceto vulgarisArtemisietum vulgaris, Chenopodio-Conyzetum canadensis, Bromo sterilis-Chelidonietum majoris)

Weed vegetation in crops (Lamio purpurei-Stellarietum mediae, Galinsogo-Portulacetum, Euphorbio-Galinsogetum ciliatae, Amarantho-Chenopodietum albi, Echinochloo cruris-galliSetarietum viridis, Echinochloo cruris-galli-Setarietum pumilae)

7. Mesotemperate and upper mesotemperate, prealpic and alpic, humid and subhumid, acidophilous (porphyritic), series of Quercus petraea [Luzulo niveae-Querceto petraeae sigmetum]; zonal, metamorphic-magmatic; developed on acid brown soils; common.

Forest (Luzulo niveae-Quercetum petraeae)

Forest plantation (Vaccinio vitis-idaeae-Pinetum sylvestris)

Scrub (Corylo-Populetum tremulae)

Scrub (Robinietum)

Xeric meadow (Tunico-Koelerietum gracilis phleetosum)

Synanthropic vegetation (Sedo albi-Poёum compressae, community of Erigeron annuus, Tanaceto vulgaris-Artemisietum vulgaris, Cichorietum intybi)

Weed vegetation in crops (Galinsogo-Portulacetum, Euphorbio-Galinsogetum ciliatae, Echinochloo cruris-galli-Setarietum viridis, Echinochloo cruris-galli-Setarietum pumilae)

Rock pioneer vegetation (Sclerantho-Sempervivetum arachnoidei)

8. Orotemperate, alpic, humid, series of Alnus viridis [Alneto viridis sigmetum]; intrazonal in Larici-Pineto cembrae and Larici-Piceeto sigmeta; northern slopes of Dosso di Costalta.

Shrub (Alnetum viridis) 
Megaforbs vegetation (Adenostylion) (fragmentary)

9. Lower supratemperate, European, humid and subhumid, peaty-swampy series of Alnus glutinosa and Carex elongata [Carici elongatae-Alneto glutinosae sigmetum]; azonal, prealpic and alpic; developed on organic soils; Paludi di Sternigo.

Forest (Carici elongatae-Alnetum glutinosae)

Scrub (Frangulo-Salicetum cinereae) (partially)

Hygrophilous meadows (Scirpetum sylvatici, Lysimachio vulgaris-Filipenduletum)

Cane thicket (Phragmitetum vulgaris)

10. Lower supratemperate, European, humid and subhumid, peaty-swampy series of Alnus glutinosa and Carex elata [Carici elatae-Alneto glutinosae sigmetum]; azonal, prealpic and alpic; developed on organic soils; Laghestel and "torbiera" of Miola.

Forest (Carici elatae-Alnetum glutinosae)

Scrub (Frangulo-Salicetum cinereae) (partially)

Marshy meadow (Caricetum elatae)

Hygrophilous meadows (Alopecuretum pratensis, Scirpetum sylvatici, Lysimachio vulgarisFilipenduletum)

Cane thicket (Phragmitetum vulgaris)

11. Montane, European, humid and subhumid, peaty-swampy series of Salix pentandra [Saliceto pentandrae sigmetum s.1.]; azonal, prealpic and alpic; developed on organic soils; Paludi di Sternigo.

Forest (Salicetum pentandrae)

Peaty meadow (Caricetum lasiocarpae, Equiseto fluviatilis-Caricetum rostratae)

12a. Supratemperate, prealpic and alpic, suboceanic and subcontinental, alluvial series of Alnus glutinosa and Stellaria nemorum [Stellario nemorum-Alneto glutinosae sigmetum]; azonal, along water courses.

Forest (Stellario nemorum-Alnetum glutinosae)

Hygrophylous meadows (Filipendulo-Epilobietum hirsuti, Scirpetum sylvatici, Lysimachio vulgaris-Filipenduletum)

Synanthropic vegetation (Juncetum macri, Echinochloo-Polygonetum lapathifolii, Arctietum lappae)

12b. Supratemperate, prealpic and alpic, suboceanic and subcontinental, alluvial series of Alnus glutinosa and Stellaria nemorum [Stellario nemorum-Alneto glutinosae sigmetum]; slopes with spring waters on hydromorphic soils.

Forest (Stellario nemorum-Alnetum glutinosae variant with Filipendulion species) Scrub (Frangulo-Viburnetum opuli)

Hygrophilous meadows (Filipendulo-Epilobietum hirsuti, Scirpetum sylvatici, Lysimachio vulgaris-Filipenduletum)

13. Supratemperate, European, humid, peaty series of Pinus sylvestris and Molinia coerulea [Molinio coeruleae-Pineto sylvestris sigmetum]; azonal, prealpic and alpic; slopes with spring 
waters on hydromorphic soils. Laghestel.

Forest (Molinio coeruleae-Pinetum sylvestris)

Scrub (Frangulo-Viburnetum opuli)

Hygrophilous meadow (Junco-Molinietum, Deschampsietum cespitosae)

14. Mesotemperate and supratemperate, European, humid and subhumid, alluvial series of Salix alba [Saliceto albae sigmetum]; azonal, prealpic and alpic; fragmentary.

Forest (Salicetum albae)

15. Series of lacustrine vegetation on organic substrate; azonal, prealpic and alpic; characterized by the following plant associations: Caricetum lasiocarpae, Equisetetum limosi, Equiseto fluviatilis-Caricetum rostratae, Caricetum elatae, Phragmitetum vulgaris, Scirpetum lacustris, Polygonetum amphibii, Ceratophylletum demersi (Serraia Lake); Charetum fragilis, Rhynchosporetum albae, Caricetum lasiocarpae, Caricetum elatae, Caricetum elatae caricetosum hartmanii (Lago Laghestel).

16. Series of lacustrine vegetation on mineral substrate; azonal, prealpic and alpic; characterized by Caricetum vesicariae; Dosedei Lake.

\section{Vegetation geoseries}

Nine geoseries were distinguished, and for each of them the following information is provided: a) the definition, b) the series (sigmeta) that compose the geoseries; c) the chorology within the study area (see also Table 1).

I - Alpic, acidophilous (porphyritic) geoseries of north-western slopes; constitutive sigmeta: Larici-Pineto cembrae; Larici-Piceeto abietis; Luzulo nemorosae-Piceeto abietis; Salvio glutinosae-Fraxineto excelsioris; northern slopes of Dosso di Costalta.

II - Prealpic, acidophilous (porphyritic) geoseries of western slopes; constitutive sigmeta: Luzulo nemorosae-Piceeto abietis; Luzulo niveae-Fageto; Salvio glutinosae-Fraxineto excelsioris; western slopes of Monte Calvo and Monte La Brada.

IIIa - Prealpic-alpic, acidophilous (porphyritic) geoseries of eastern, southern and western slopes; constitutive sigmeta: Vaccinio vitis-idaeae-Pineto sylvestris; Luzulo niveae-Quercetum petraeae; Salvio glutinosae-Fraxineto excelsioris; common.

IIIb - Prealpic-alpic, acidophilous (porphyritic) geoseries of highlands; constitutive sigmeta: same as above. It is similar to the previous geoseries, but lies mostly on the flat part of the plateau.

IV - Alpic, acidophilous (porphyritic) geoseries of brooks and furrows; constitutive sigmeta: Alneto viridis; northern slopes of Dosso di Costalta.

V - Prealpic-alpic geoseries of valley bottoms (ancient lake basins); constitutive sigmeta: Carici elongatae-Alneto glutinosae; Carici elatae-Alneto glutinosae.; Saliceto pentandrae s.1.; 
valley bottoms, near the lakes Serraia and Laghestel and "torbiera" of Miola.

VI - Prealpic-alpic geoseries of floodplains (along the water courses); constitutive sigmeta: Stellario nemorum-Alneto glutinosae and Saliceto albae.

VII - Prealpic-alpic, acidophilous (porphyritic) geoseries of slopes with spring waters; constitutive sigmeta: Molinio coeruleae-Pineto sylvestris, Stellario nemorum-Alneto glutinosae.

VIII - Prealpic-alpic, lacustrine geoseries on organic substrate; constitutive associations: Equisetetum limosi, Caricetum lasiocarpae, Equiseto fluviatilis-Caricetum rostratae, Phragmitetum vulgaris, Scirpetum lacustris, Caricetum elatae, Community of Polygonum minus, Community of Sparganium erectum, Polygonetum amphibii, Ceratophylletum submersi (Serraia Lake); Charetum fragilis, Rhynchosporetum albae, Caricetum lasiocarpae, Caricetum elatae, Caricetum elatae caricetosum hartmanii (Laghestel).

IX - Prealpic-alpic, lacustrine geoseries on mineral substrate; constitutive associations: Caricetum vesicariae; Dosedei Lake.

Table 1: Vegetation series (sigmeta) composition of the geosigmeta (geoseries) distinguished in the Pine' Highland (names of coded geoseries as in Fig. 2).

\begin{tabular}{|c|c|c|c|c|c|c|c|c|c|}
\hline \multirow{2}{*}{ Sigmeta } & \multicolumn{9}{|c|}{ Geosigmeta (geoseries) } \\
\hline & I & II & III a/b & IV & $\mathrm{V}$ & VI & VII & VII & IX \\
\hline Larici-Pineto cembrae & + & . & . & . & . & . & . & . & . \\
\hline Larici-Piceeto abietis & + & . & . & . & . & . & . & . & . \\
\hline Luzulo nemorosae-Piceeto abietis & + & + & . & . & . & . & . & . & . \\
\hline Salvio glutinosae-Fraxineto excelsioris & + & + & + & . & . & . & . & . & . \\
\hline Luzulo niveae-Fageto sylvaticae & . & + & . & . & . & . & . & . & . \\
\hline Luzulo niveae-Querceto petraeae & . & + & + & . & . & . & . & . & . \\
\hline Vaccinio vitis-idaeae-Pineto sylvestris & . & . & + & . & . & . & . & . & . \\
\hline Alneto viridis & . & . & . & + & . & . & . & . & . \\
\hline Carici elongatae-Alneto glutinosae & . & . & . & . & + & . & . & . & . \\
\hline Carici elatae-Alneto glutinosae & . & . & . & . & + & . & . & . & . \\
\hline Saliceto pentandrae & . & . & . & . & + & . & . & . & . \\
\hline Stellario nemorum-Alneto glutinosae (riparian) & . & . & . & . & . & + & . & . & . \\
\hline Saliceto albae & . & . & . & . & . & + & . & . & . \\
\hline Stellario nemorum-Alneto glutinosae (on slopes) & . & . & . & . & . & . & + & . & . \\
\hline Molinio caeruleae-Pineto sylvestris & . & . & . & . & . & . & + & . & . \\
\hline Series of lacustrine vegetation on organic substrata & . & . & . & . & . & . & . & + & . \\
\hline Series of lacustrine vegetation on mineral substrata & . & . & . & . & . & . & . & . & + \\
\hline
\end{tabular}

\section{Stereograms}

Three stereograms in scale 1: 40,000 were realized: one of the vegetation series (Fig. 1), one of the geoseries (Fig. 2) and one of the phytoclimatic sectors (Fig. 3).

The appealing feature of these stereograms is that the geomorphology and hidrography of the area studied can be evaluated at a glance.

Each geoseries has developed under certain environmental conditions (orography, 
geomorphology, exposure) and is characterized by one or more vegetation series (Table 1). Some geoseries shares one or more vegetation series. For instance, Salvio glutinosae-Fraxineto excelsioris sigmetum is present in three geoseries.

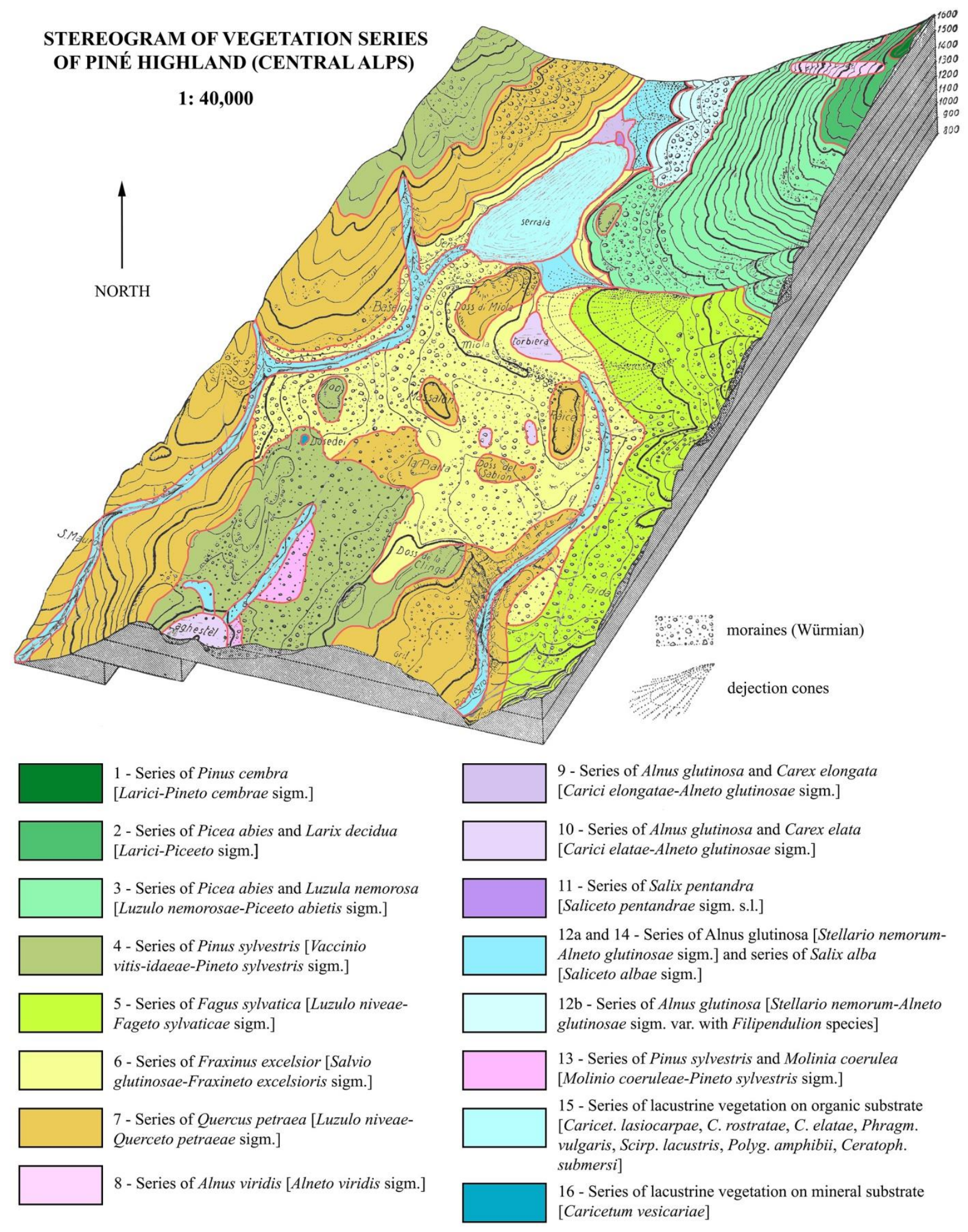

Fig. 1: - Stereogram of vegetation series of the Piné Highland (central Alps). 

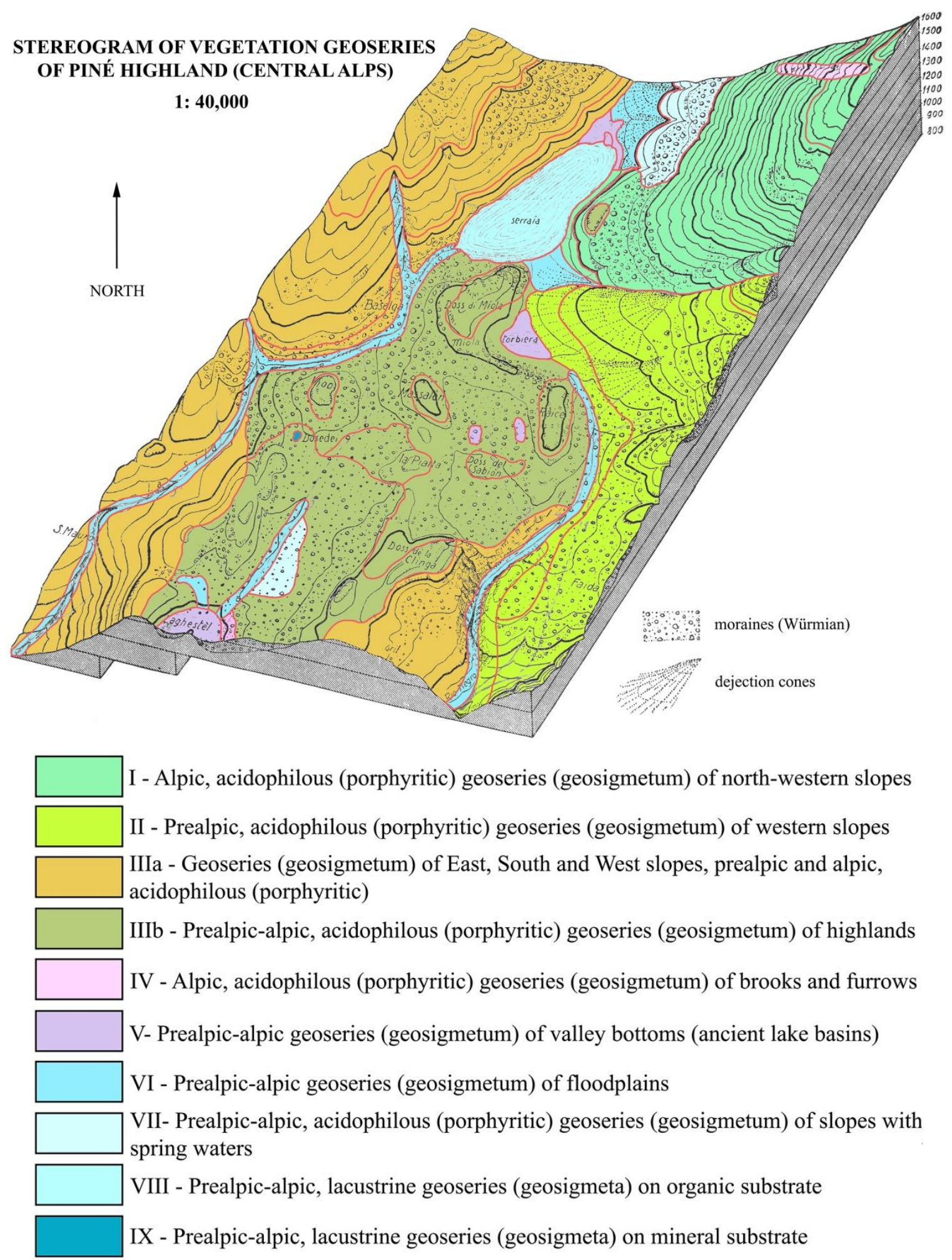

Fig. 2: Stereogram of vegetation geoseries of the Piné Highland (central Alps).

It should be noted that the evaluation of the geoseries was done exclusively within the area represented in the stereogram, and therefore the geoseries are not complete, but truncated (sensu Pedrotti, 2017a, Pedrotti, in print - a) at the base (below $800 \mathrm{~m}$ ) or above (over $1600 \mathrm{~m}$ ). 
Consequently, no geoseries is complete on the stereogram, inasmuch as some geoseries are cut off above, over $1600 \mathrm{~m}$, and others below, under $800 \mathrm{~m}$. The following zonal vegetation series lie out of the stereogram: a) orotemperate, alpic, humid acidophilous (metamorphic-magmatic) series of Rhododendron ferrugineum [Rhododendreto ferruginei sigmetum], developed above $1600 \mathrm{~m}$ on Dosso di Costalta; b) mesotemperate and upper mesotemperate, prealpic, acidophilous (porphyritic) series of Carpinus betulus [Galio laevigati-Carpineto betuli sigmetum], distributed at the base of the porphyry escarpment, below $800 \mathrm{~m}$, between Le Sille and Canzolino.

For a general evaluation of the geoseries, it is necessary to take into consideration a vaster territory that encompasses the entire altitudinal range; in such a case, the series would be complete.

On the stereograms, 16 vegetation series and 9 geoseries were represented (Fig. 1 and Fig. 2). In order to facilitate reading of maps and their comparison, the limits of the series within their geoseries were maintained on the stereogram of the vegetation geoseries (Fig. 2).

\section{Limit between the prealpic and alpic sectors}

In order to identify the limit between the two phytoclimatic sectors (prealpic and alpic) in the stereogram of the Piné Highland, a third stereogram (Fig. 3) was prepared by assigning the zonal and extrazonal geoseries to the respective sectors and comparing it with the phytoclimatic map of Trentino-Alto Adige (Gafta and Pedrotti, 1998).

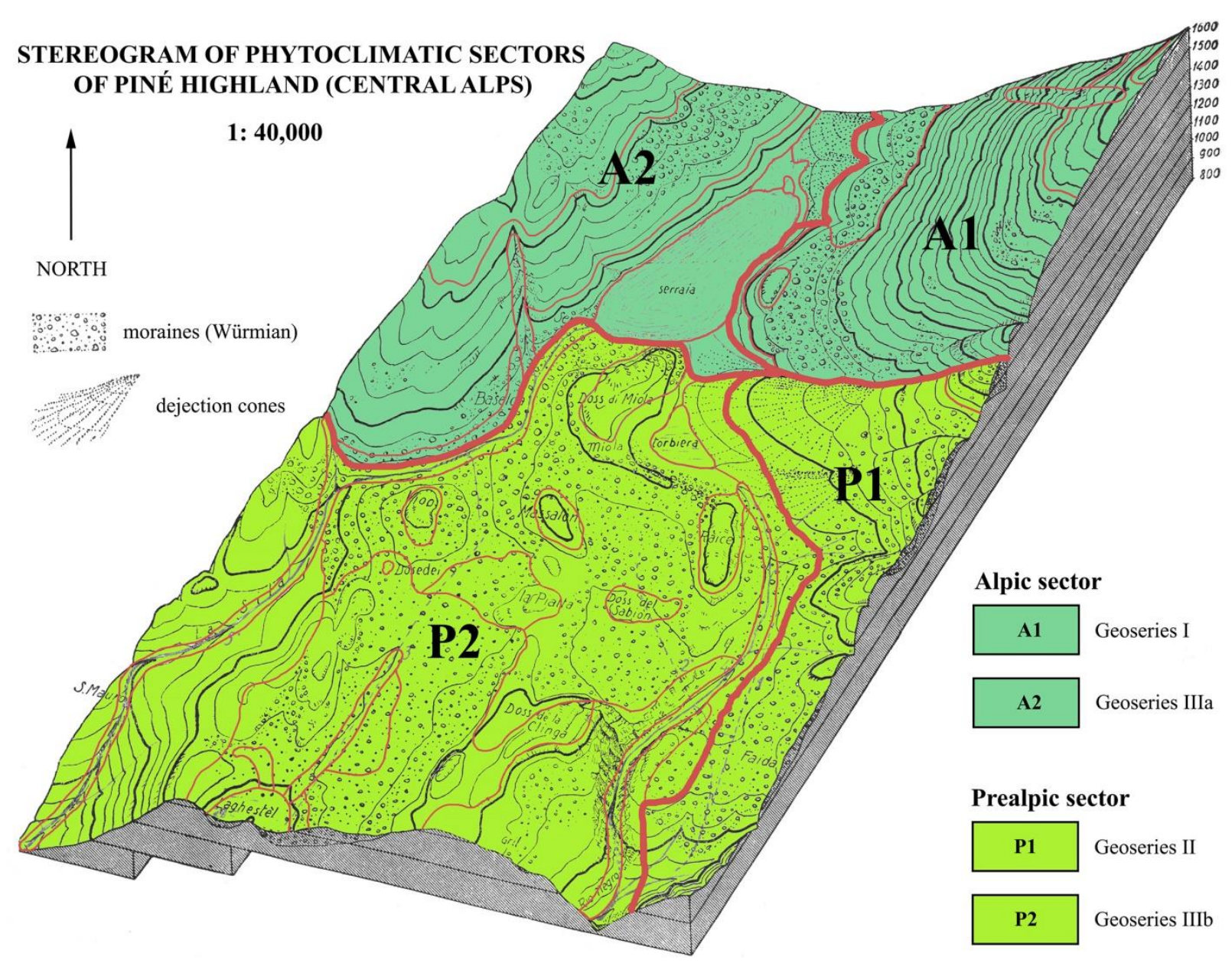

Fig. 3: Stereogram of phytoclimatic sectors of the Piné Highland (central Alps). 
The vegetation of the Vaccinio-Piceetalia order (Larici-Pinetum cembrae, LariciPiceetum and Luzulo nemorosae-Piceetum characterizing the geoseries I) is typical of the alpic sector. Also Vaccinio vitis-idaeae-Pinetum sylvestris is typical of the alpic sector, but on the porphyritic highland it tends to pass into the prealpic sector as well, for example on the Dossi di Tressilla. The typical vegetation of the prealpic sector is that of the Fagetalia sylvaticae order (Luzulo niveae-Fagetum). The Salvio glutinosae-Fraxinetum excelsioris forest association, instead, has a particular distribution. In Lombardy it occurs only in the prealpic sector, but in Trentino Alto-Adige it extends from the prealpic sector to different valleys of the alpic sector, and even reaches the inneralpic one. This ash-dominated forest has a much larger distribution than that of beechwoods. Luzulo niveae-Quercetum petraeae is also prealpic, but it also extends into the alpic and inneralpic ones. The stereogram (Fig. 3) is thus divided as follows:

Alpic sector (A) with two subunits: A1 and A2 featuring the geoseries I and respectively, IIIa; Prealpic sector (P) with two subunits: P1 and P2 featuring the geoseries II and respectively, IIIb.

\section{Concluding remarks}

The three-dimensional representation of vegetation using stereograms is appealing because it shows the relationships between the vegetation distribution and physical factors (orography and gomorphology) and climatic ones (phytoclimate). At not too large scales (i.e., $<1: 10000$ ), many geomorphotypes can be visualized along with their typical vegetation series. All this information can be completed with the division into different phytoclimatic sectors.

The use of stereograms is particulary useful for mapping areas of limited extension displaying a high beta-diversity (between-vegetation stand diversity), which is determined by a wide altitudinal range, and/or heterogeneous geomorphotypes and mesoclimatic types (mediumscale environmental heterogeneity).

\section{REFERENCES}

1. Bioret, F., Quénot, F., 2012, Uuessant, Atlas environnemental, Les cahiers du CEMO, 4: 1-128.

2. Bioret, F., Chalumeau, A., Perrin, G., Caillon, N., Le Bihan, O., Glemarec, C., Gauberville, C., Lalanne, A., 2014, Colloque international, Brest 2014, La phytosociologie paysagère: des concepts aux applications, Guide de l'excursion dans les Côtes-d'Armor, Doc. Phytosoc., h.s. 1: 1-152.

3. Dell'Uomo, A., 1981, Studio algologico del bacino torboso-palustre del Laghestel (Trento), St. Trent. Sc. Nat., 58: 169-250.

4. Gafta, D., 2006, Ecocoenotic distinctiveness of an extrazonal ice hole biotope in the Valley of Cembra (southern central Alps, Trentino), Polish Botanical Studies, 22: 195-206.

5. Gafta, D., Canullo, R., 1992, The role of Alnus glutinosa (L.) Gaertner in the secondary succession on wet meadows in the Piné High Plain (north Italy), Studia Geobotanica, 12: 105-120.

6. Gafta, D., Pedrotti, F., 1998, Fitoclima del Trentino-Alto Adige, St. Trent. Sc. Nat., 73: 55-11.

7. Lanzinger, M., Sartori, G., 2004, Carta geologica con indicazioni pedologiche del Biotopo del Laghestel. In: Pedrotti F., 2004, Ricerche geobotaniche al Laghestel di Piné (1967-2001), Braun-Blanquetia, 35: 1-55.

8. Lona, F., 1941, Analisi polliniche di due torbiere del Trentino, St. Trent. Sc. Nat., 22(3): 149-171.

9. Mazzoleni, C., 1929, Una marmitta dei giganti in Val di Piné (Trento), St. Trent. Sc. Nat., 10(1): 60-61.

10. Pedrotti, F., 1981, Carta della vegetazione del Foglio Trento. Collana Programma Finalizzato "Promozione qualità ambiente”, Roma, C.N.R., AQ/1/85: 1-25.

11. Pedrotti, F., 1988, Alterazioni del paesaggio delle montagne del Trentino a seguito dei cambiamenti dell'uso 
del suolo, Coll. Phytosoc., XVII: 207-220.

12. Pedrotti, F., 2003, Il lago e il suo biotopo. Atti convegno: Il Lago della Serraia: Verso il suo recupero (Baselga di Piné, 18 maggio 2002), Trento, Tip. Esperia: 41-44.

13. Pedrotti, F., 2004, Ricerche geobotaniche al Laghestel di Piné (1967- 2001), Braun-Blanquetia, 35: 1-55.

14. Pedrotti, F., 2006, Die Änderungen der Vegetation in Feuchtgebieten des Trentino in den letzen 50 Jahren, Sauteria, 14: 133-149.

15. Pedrotti, F., 2016, Guida all'escursione della Società Botanica Italiana al Lago della Serraia (Altopiano di Piné), Società Botanica Italiana, Firenze (IIa ed.).

16. Pedrotti, F., 2010, Neofitismo e associazioni vegetali, Braun-Blanquetia, 46: 345-349.

17. Pedrotti, F., 2017a, Concepts et applications de la Phytosociologie paysagère, Doc. Phytosoc. n.s., 6: 439-444.

18. Pedrotti, F., 2017b, Vegetation series along climatic gradients in the Central Southern Alps (Trentino - Alto Adige Region). In: Pedrotti F. (ed.), Climate gradients and biodiversity in mountains of Italy, pp. 51-81. Geobotany Studies, Springer, Heidelberg.

19. Pedrotti, F., in print - a, Interpretation and geobotanical significance of geoseries, Acta Botanica Gallica.

20. Pedrotti F., in print - b, Essai de cartographie géobotanique (végétation, bioclimat et environnement) de la Val di Sole (Alpes centrales, Italie), Doc. Phytosoc. n.s.

21. Pedrotti, F., Chemini, C., 1981, La vegetazione del Laghestel di Piné (Trento), St. Trent. Sc. Nat., 58: 425-462.

22. Pedrotti, F., Gafta, D., 1997, Long-term changes in the vegetation of a protected wetland (Laghestel) in the Italian Alps, Studii Cercetări Biologie, Ser. Biologie vegetală, 49(1-2): 5-16.

23. Perrin, G., 2014, Étang du Moulin Neuf. In: Bioret, F., Chalumeau, A., Perrin, G., Caillon, N., Le Bihan, O., Glemarec, C., Gauberville, C., Lalanne, A., 2014, Colloque international. Brest 2014. La phytosociologie paysagère: des concepts aux applications. Guide de l'excursion dans les Côtes-d'Armor, Doc. Phytosoc., h.s. 1: $121-152$.

24. Rivas-Martìnez, S., 1987, Memoria del mapa de series de vegetaciòn de Españ,. I.C.O.N.A., Madrid.

25. Rivas-Martìnez, S. et al., 2007, Mapa de series, geoseries y geopermaseries de vegetaciòn de España [Memoria del mapa de vegetaciòn potencial de España]. Parte I, Itinera Geobotanica, n.s., 17: 5 - 435.

26. Rivas-Martìnez, S. et al., 2011a, Mapa de series, geoseries y geopermaseries de vegetaciòn de España [Memoria del mapa de vegetaciòn potencial de España]. Parte II, Itinera Geobotanica, n.s., 18(1): 5 - 424.

27. Rivas-Martìnez, S. et al., 2011b, Mapa de series, geoseries y geopermaseries de vegetaciòn de España [Memoria del mapa de vegetaciòn potencial de España]. Parte II, Itinera Geobotanica, n.s., 18(2): 425 - 800.

28. Tomasi, G., 1962, Origine, distribuzione, catasto e bibliografia dei laghi del Trentino, St. Trent. Sc. Nat., 39(1-2): 3-355.

29. Trevisan, L., 1943, Evoluzione morfologica della Val di Piné (Trento), St. Trent. Sc. Nat., XXIV(1): 3-14.

30. Venanzoni, R., 1988, I prati umidi (Calthion) del Lago della Serraia (Trentino), Coll. Phytosoc., XVI: 835845 .

\section{UTILIZAREA STEREOGRAMELOR ÎN HĂRȚI TRIDIMENSIONALE ALE SERIILOR DE VEGETAŢIE ŞI GEOSERIILOR}

\section{(Rezumat)}

Lucrarea prezintă un model tridimensional pentru cartografierea vegetației la diferite nivele de integrare prin utilizarea unei stereograme. Metoda clasică folosită în cartografierea vegetaţiei este cea a hărţilor de vegetație (model bidimensional). Cartografia tridimensională, prin stereograme, reprezintă un pas înainte deoarece evidenţiază relațiile dintre distribuția vegetației și, factorii fizici (orografia şi geomorfologia) şi cei climatici (fitoclimat). Zona cartografiată este Altipiano di Piné (Podişul Piné), situat între 800 și 1600 de metri altitudine în Alpii Centrali, Provincia Trentino, Italia. Au fost realizate trei stereograme, una pentru seriile de vegetație (în număr de 16), una pentru geoserii (în număr de 9) și una pentru sectoarele fitoclimatice (în număr de 2). Folosirea stereogramelor este utilă în special pentru cartografierea zonelor cu extindere limitată, care prezintă o beta diversitate ridicată a vegetației determinată de o mare amplitudine altitudinală și / sau geomorfotipuri heterogene și tipuri mezoclimatice diferite (heterogenitate ambientală la scară medie). 